\title{
Implementasi Aplikasi Notifikasi Berbasis SMS Gateway Pada Unit Usaha Kecil dan Menengah Koperasi Wanita Setia Bhakti Wanita Jawa Timur
}

\author{
Teguh Sutanto ${ }^{1 *}$, Norma Ningsih ${ }^{2}$, Harianto $^{3}$ \\ 1,2,3Universitas Dinamika \\ e-mail: teguh@dinamika.ac.id ${ }^{1}$,norma@dinamika.ac.id ${ }^{2}$, hari@dinamika.ac.id ${ }^{3}$ \\ *Penulis Korespondensi: E-mail: teguh@dinamika.ac.id
}

\begin{abstract}
Small and Medium Enterprises Unit (UKM) Women's Cooperative Setia Bhakti Wanita East Java is one of the cooperative business units that serve savings and loan members. Currently the SME Unit is already using the UKM Application to carry out daily business processes. The UKM application does not yet have a function to display a loan dashboard and SMS notifications to members who have loans that are past due. Based on this, this community service proposes the implementation of an SMS Gateway-based notification application that can provide information on loans that will, are currently and have matured and send messages to members whose loans will, are currently and have matured. The implementation method in this activity generally consists of: Planning, Analysis, Design and Implementation. Implementation of the activity from January 1, 2019 to July 30, 2019. This community service activity helps cooperatives in solving problems related to maturity information and loan notifications at the UKM Unit by creating an SMS Gateway-based notification application. The way the notification application works starts from reading the billing data, showing it to the Billing View page, sending SMS Notifications, and providing reports on the results of SMS sending. There is an application weakness in the bill reading process which is still carried out manually, namely importing from a text file exported by the UKM System. The next development suggestion is to migrate the UKM system base from file data to relational database so that bills can be automatically entered into the Bills table on the SMS Gateway-based Notification Application.
\end{abstract}

Keywords: Gammu, GSM modem, SMS, SMS Gateway

Abstrak
Unit Usaha Kecil dan Menengan (UKM) Koperasi Wanita Setia Bhakti Wanita Jawa Timur
adalah salah satu unit usaha koperasi yang melayani simpan dan pinjam anggota. Saat ini
Unit UKM sudah menggunakan Aplikasi UKM untuk melaksanakan proses bisnis sehari-
hari. Aplikasi UKM belum memiliki fungsi untuk menampilkan dashboard pinjaman dan
notifikasi SMS kepada anggota yang memiliki pinjaman yang sudah jatuh tempo.
Berdasarkan hal tersebut maka pengabdian masyarakat ini mengusulkan implementasi
aplikasi notifikasi berbasis SMS Gateway yang dapat memberikan informasi pinjaman
yang akan, sedang dan telah jatuh tempo serta mengirimkan pesan kepada anggota yang
pinjamannya akan, sedang dan telah jatuh tempo. Metode pelaksanaan dalam kegiatan ini
secara umum terdiri dari: Perencanaan, Analisis, Desain dan Implementasi. Pelaksanaan
kegiata mulai 1 Januari 2019 sampai dengan 30 Juli 2019 . Kegiatan pengabdian
masyarakat ini membantu koperasi dalam menyelesaikan permasalahan terkait
informasi jatuh tempo dan notifikasi pinjaman pada Unit UKM dengan cara pembuatan
aplikasi notifikasi berbasis SMS Gateway. Cara kerja aplikasi notifikasi dimulai dari
pembacaan data tagihan, menampilkan ke halaman View Tagihan, Pengiriman SMS
Notifikasi, dan memberikan laporan hasil pengiriman SMS. Terdapat kekurangan aplikasi


pada proses pembacaan tagihan yang masih dilaksanakan secara manual yaitu mengimport dari file teks yang dieksport oleh System UKM. Saran pengembangan berikutnya adalah melakukan migrasi basis System UKM dari data file ke basis data relasional sehingga tagihan bisa secara otomatis masuk ke dalam tabel Tagihan pada Aplikasi Notifikasi berbasis SMS Gateway.

Kata Kunci : Gammu, GSM modem, SMS, SMS Gateway

\section{PENDAHULUAN}

Unit Usaha Kecil dan Menengah (UKM) adalah salah satu unit pada Koperasi Wanita Setia Bhakti Wanita Jawa Timur yang beralamat di Jl. Jemur Andayani No.55 Surabaya. Peta lokasi koperasi dapat dilihat pada Gambar 1. Proses bisnis utama koperasi Wanita Setia Bhakti Wanita Jawa Timur adalah Simpan, Pinjam dan Transaksi pada swalayan koperasi (Semaun, 2018).

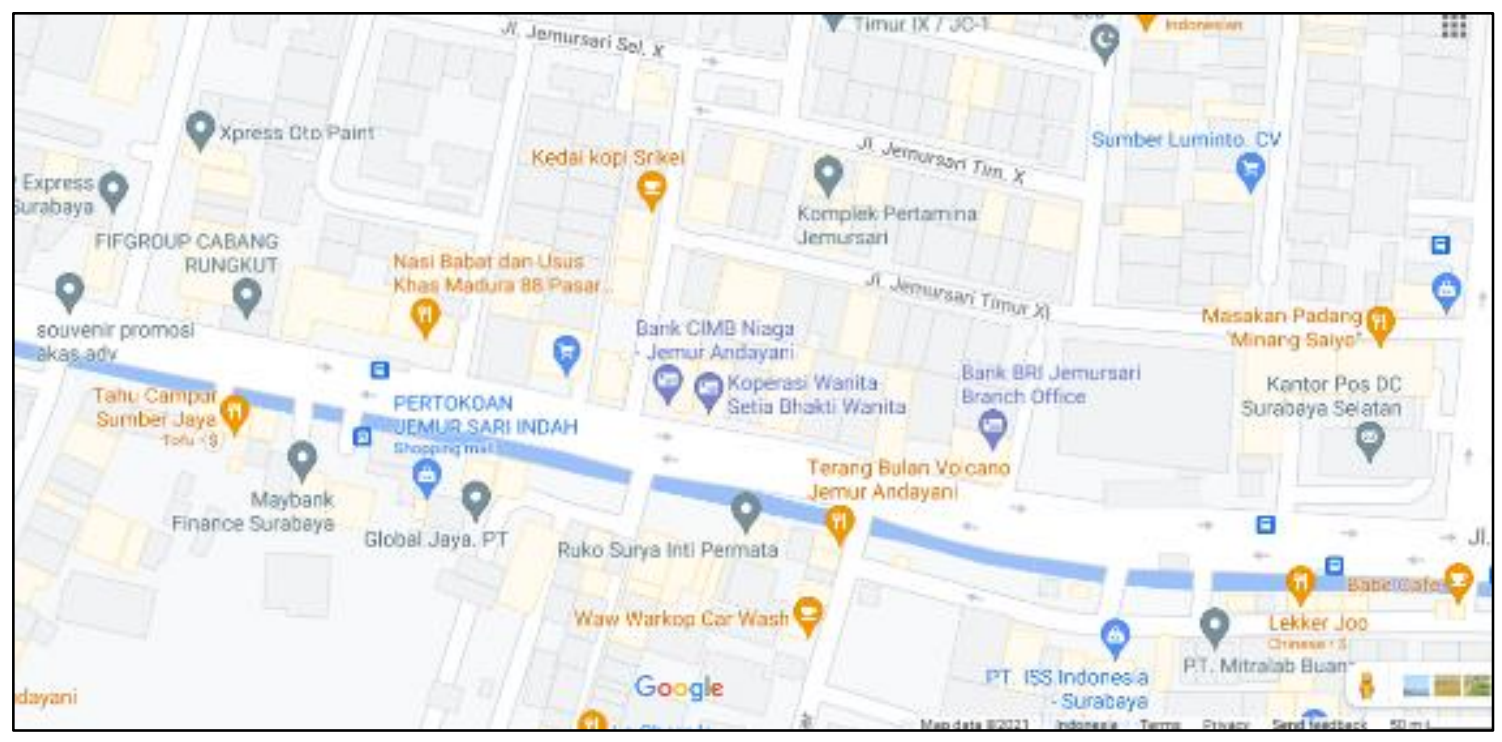

Gambar 1. Peta Lokasi Koperasi Wanita Setia Bhakti Wanita Jawa Timur

(Sumber: Google Maps https://www.google.com/maps/@-7.328544,112.741767,18z)

Unit UKM memiliki proses bisnis simpan dan pinjam bagi anggota Koperasi Wanita Setia Bhakti Wanita Jawa Timur. Anggota dapat melakukan pinjaman dengan cara mengajukan pinjaman, mengirimkan berkas dokumen yang dibutuhkan, menerima keputusan terkait pengajuan pinjaman, pencairan pinjaman dan pembayaran angsuran atau pelunasan pinjaman. Saat ini Unit UKM sudah menggunakan Aplikasi UKM dalam melaksananakan proses bisnis sehari-hari. Aplikasi UKM saat ini belum ada fungsi untuk proses pengajuan pinjaman dan pemberian peringatan terhadap anggota yang pinjamannya akan, sedang dan melebihi jatuh tempo. Jika ada pinjaman yang jatuh tempo maka karyawan Unit UKM (PJ Pinjaman) akan mengirimkan pesan kepada anggota yang jatuh tempo secara manual menggunakan telepon seluler. Dengan cara kerja seperti ini maka akan mengalami kesulitan jika harus mengirimkan notifikasi ke anggota dengan jumlah yang besar dan dengan berbagai macam jenis pinjaman. Dengan pengiriman notifikasi SMS secara manual maka riwayat pengiriman SMS tidak tercatat dengan baik.

Permasalahan yang dihadapi mitra adalah tidak adanya sistem yang memberikan peringatan kepada anggota koperasi terkait status pengajuan pinjaman dan jatuh tempo pinjaman. Berdasarkan permasalahan tersebut maka Koperasi Wanita Setia Bhakti Wanita 
Jawa Timur membutuhkan aplikasi yang dapat menampilkan informasi tentang ringkasan tagihan yang jatuh tempo berupa tampilan dashboard (Sulistiawati \& Sulistiani, 2017), memberikan pesan notifikasi melalui SMS kepada anggota pada saat proses pengajuan pinjaman dan status jatuh tempo pinjaman.

Kegiatan pengabdian masyarakat ini membantu koperasi dalam menyelesaikan permasalan terkait informasi jatuh tempo dan notifikasi pinjaman pada Unit UKM dengan cara pembuatan aplikasi notifikasi berbasis SMS Gateway. Short Message Service(SMS) adalah salah satu fitur dari telepon selular yang memungkinkan untuk menerima dan mengirim pesan singkat berupa teks yang dapat berisi karakter dan angka. SMS Gateway merupakan gerbang untuk mengirimkan, menerima dan memproses SMS (Laraswati \& Syam, 2019). Pemilihan SMS sebagai media pengiriman pesan karena SMS adalah mekanisme pengiriman data yang sederhana dan dapat digunakan oleh semua perangkat telepon seluler. Pelaksanan kegiatan mengikuti fase pengembangan perangkat lunak yang meliputi: perencanaan, analisis, desain dan implementasi (DENNIS, WIXOM, \& ROTH, 2012) (Unhelkar, 2018). Dengan adanya aplikasi nofikasi SMS maka anggota dapat mngetahui status pengajuan pinjamannya sehingga jika terdapat persyaratan yang kurang maka anggota bisa segera melengkapi persyaratan dan mengajukan pinjaman ulang. Bagi Unit UKM, aplikasi notifikasi berbasis SMS Gateway tersebut dapat mengurangi pinjaman macet, karena secara berkala sistem dapat mengirimkan pesan kepada anggota yang pinjamannya akan, sedang dan melewati jatuh tempo.

\section{METODE PELAKSANAAN}

Metode pelaksanaan dalam kegiatan ini secara umum terdiri dari: Perencanaan, Analisis, Desain dan Implementasi (lihat Gambar 2). Tahapan pertama adalah proses perencanaan terdiri dari kegiatan: survey dan wawancara, pembuatan dokumentasi proses bisnis Unit UKM dan pembuatan working plan. Tahap kedua adalah Analisis yang terdiri dari kegiatan: rekayasa kebutuhan dan pembuatan spesifikasi kebutuhan. Berdasarkan spesifikasi kebutuhan pada tahap Analisis, maka tahap berikutnya adalah membuat desain aplikasi yang terdiri dari: pembuatan desain use case dan pembuatan desain user interface.

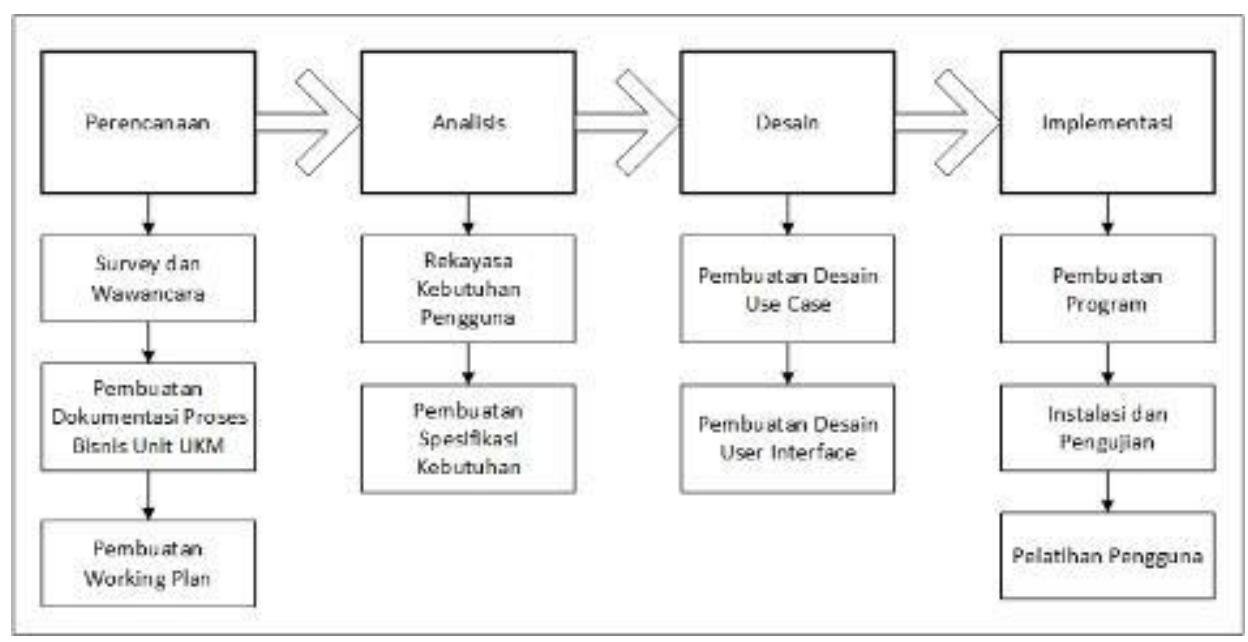

Gambar 2. Metode Pelaksanaan

Tahap terakhir adalah implementasi yang terdiri dari: pembuatan program, proses instalasi dan pengujian, dan ditutup dengan pelatihan pengguna. Tahapan implementasi ini akan menghasilkan aplikasi notifikasi berbasis SMS Gateway yang dapat memberikan pesan notifikasi terhadap transaksi keuangan yang ada pada Unit UKM. 


\section{Perencanaan}

Perencanaan merupakan proses awal dalam pengembangan perangkat lunak atau aplikasi komputer. Perencanaan memiliki peranan penting dalam pembuatan program (DENNIS, WIXOM, \& ROTH, 2012), karena pada tahap ini akan menghasilkan motivasi atau alasan penting mengapa program akan dibuat, dan rancana kerja yang berisi jadwal kerja beserta penanggung jawab atas pekerjaan tersebut. Detai dari kegiatan perencanaan dapat dilihat pada Tabel 1.

Tabel 1. Proses Perencanaan

\begin{tabular}{|c|c|c|c|}
\hline No. & Kegiatan & Waktu & Hasil \\
\hline 1. & Survey dan Wawancana & Minggu Ke 1 - Januari 2019 & $\begin{array}{l}\text { Deskripsi Proses bisnis } \\
\text { Unit UKM }\end{array}$ \\
\hline 2. & Pemodelan Bisnis & Minggu ke 2 - Januari 2019 & Diagram Use Case Bisnis \\
\hline 3. & Pembuatan Working Plan & Minggu Ke 3 - Januari 2019 & Working Plan \\
\hline
\end{tabular}

\section{Analisis}

Proses analisis dilaksanakan untuk menemukan kebutuhan pengguna terhadap aplikasi yang akan dibangun. Hasil kegiatan analisis yang dilaksanakan pada tanggal 11 February 2019 adalah berupa fitur apa saja yang dibutuhkan oleh pengguna. Berikut ini adalah fitur-fitur yang akan dibuat dalam aplikasi:
1. Mengimport Data Tagihan
2. Melihat Data Tunggakan
3. Mengirimkan Reminder
4. Penyaringan Data Pelanggan
5. Modul Pengajuan Pinjaman
6. Mengirimkan SMS Status Pengajuan Pinjaman
7. Membuat Rekap Pengajuan Pinjaman
8. Menampilkan Rekap
9. Menerima SMS Pelanggan

\section{Desain} meliputi:

Dalam kegiatan pengabdian masyarakat ini proses desain yang dilaksanakan

1. Pembuatan Digaram Use Case, diagram ini menggambarkan fitur yang akan diimplementasikan dalam aplikasi notifikasi berbasis SMS Gateway ini (Unhelkar, 2018).

2. Pembuatan Desain User Interface, desain ini menggambarkan user interface atau boundary antara pengguna(actor) dengan program (sistem) (DENNIS, WIXOM, \& ROTH, 2012).

\section{Implementasi}

Secara umum kegiatan implementasi terdiri dari: konstruksi (pembuatan aplikasi), instalasi dan pelatihan pengguna. Pembuatan aplikasi menggunakan Bahasa Pemrograman PHP dan basis data relasional dengan server basis data MySQL Server. Dalam rangka implementasi aplikasi maka perlu dibuat desain arsitektur (Sulianta, 2019). Arsitektur aplikasi yang dibutuhkan dalam proses instalasi dapat dilihat pada Gambar 3. 


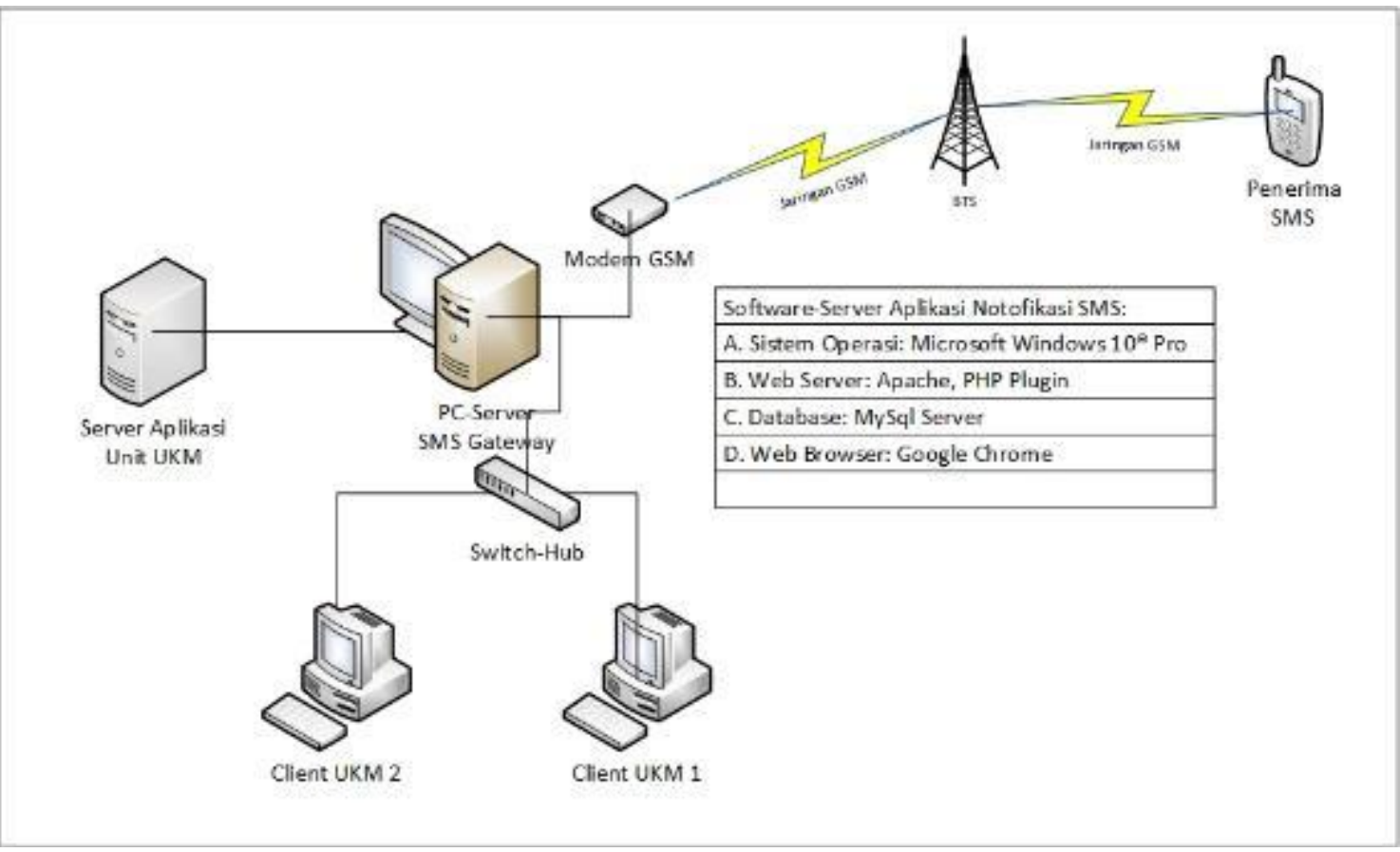

Gambar 3. Arsitektur Aplikasi

Supaya program dapat berjalan dengan baik maka proses instalasi membutuhkan perangkat keras sebagai berikut:

1. Seperangkat computer personal

2. Modem GSM

3. Kartu Perdana GSM (paket SMS)

4. Switch hub

Sedangkan perangkat lunak yang dibutuhkan adalah:

1. Web Server: Apache

2. Server Database : MySQL

3. Gammy Library

4. Web Browser: Google Chrome

\section{HASIL dan PEMBAHASAN}

Hasil kegiatan pengabdian masyarakat ini adalah berupa aplikasi notifikasi SMS yang jalan di sebuah web server (Apache). Untuk menjalankan aplikasi dari sisi pengguna dibutuhkan program Web Browser Google Chrome. Tampilan awal program adalah berupa halaman login seperti pada Gambar 4. Setelah berhasil melakukan proses login maka program akan menampilkan halaman Dashboard seperti pada Gambar 5. 


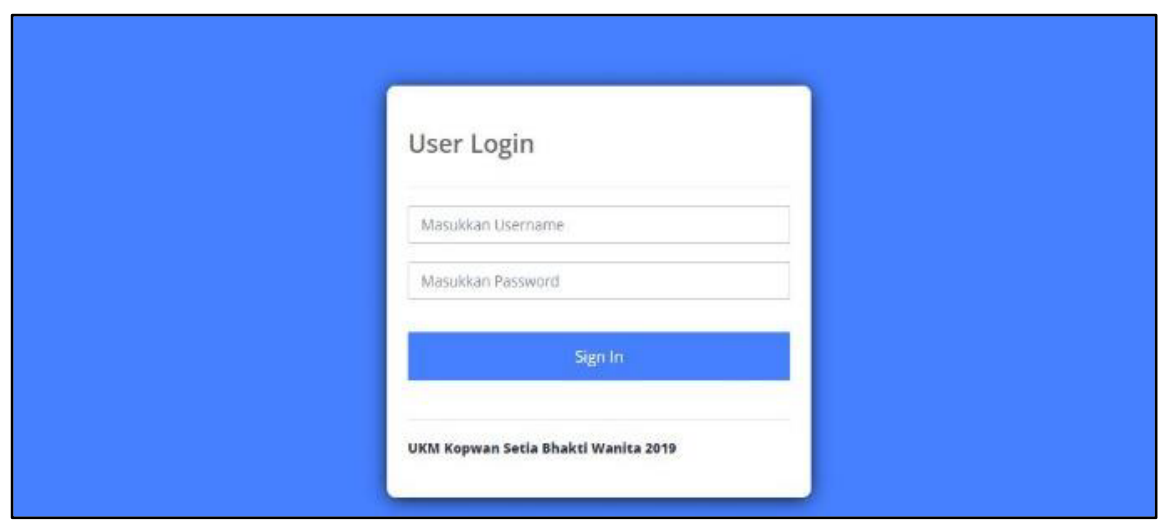

Gambar 4. Halaman Login

Halaman Dashboard berisi fitur utama dari aplikasi notifikasi SMS. Terdapat menu: Upload Data Tagihan, Input Data Pengajuan, Laporan dan Logout. Selain menampilkan menu, pada halaman Dashboard juga menampilkan ringkasan dan jumlah Tagihan Lewat Jatuh Tempo, Sedang Jatuh Tempo (pada hari H), Jatuh Tempo sampai dengan 7 hari dan Jatuh Tempo melebihi 7 hari.

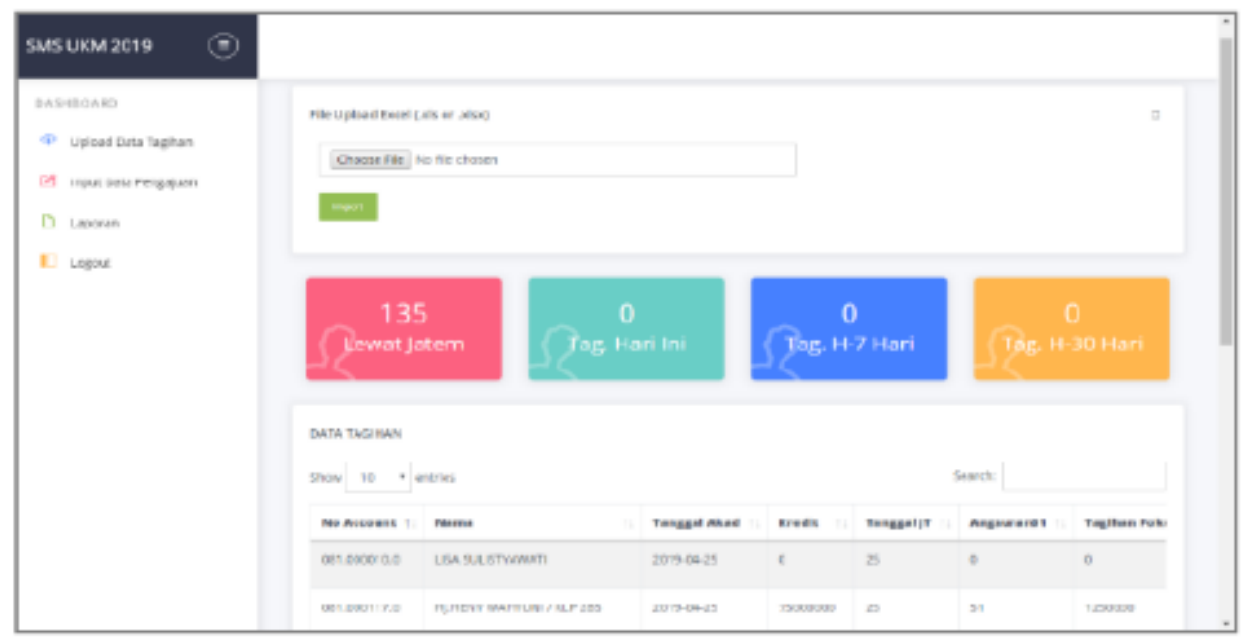

Gambar 5. Halaman Dashboard

Menu input data pengajuan akan menampilkan formulir isian untuk memasukkan data pengajuan pinjaman (lihat Gambar 6). Data pengajuan pinjaman terdiri dari: kode, nomor antrian pengajuan, Nama Lengkap, Tanggal Pinjaman, Nominal, Nomor Telpon, Alamat, Status Pinjaman dan Keterangan. Menu input pengajuan juga berfungsi untuk melakukan perubahan status pengajuan pinjaman. 


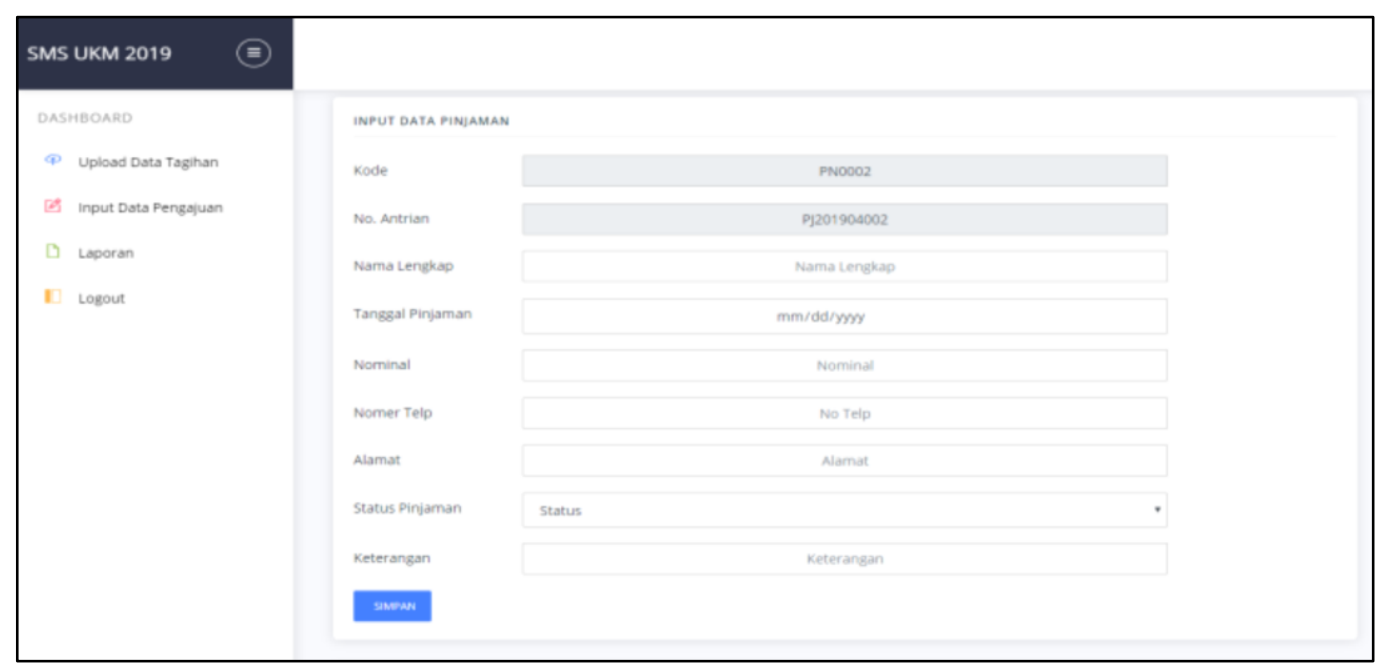

Gambar 6. Form Input Pengajuan Pinjaman

Untuk menambahkan data pengajuan baru, pengguna hanya perlu mengisi form pengisian data yang telah disediakan. Apabila keseluruhan data telah diisi, maka pengguna dapat menekan tombol "SIMPAN" untuk menyimpan data pengajuan baru yang telah ditambahkan. Data pengajuan baru yang telah tersimpan akan ditampilkan secara otomatis pada tabel Data Pengajuan yang terdapat pada sisi bawah form pengisian data.

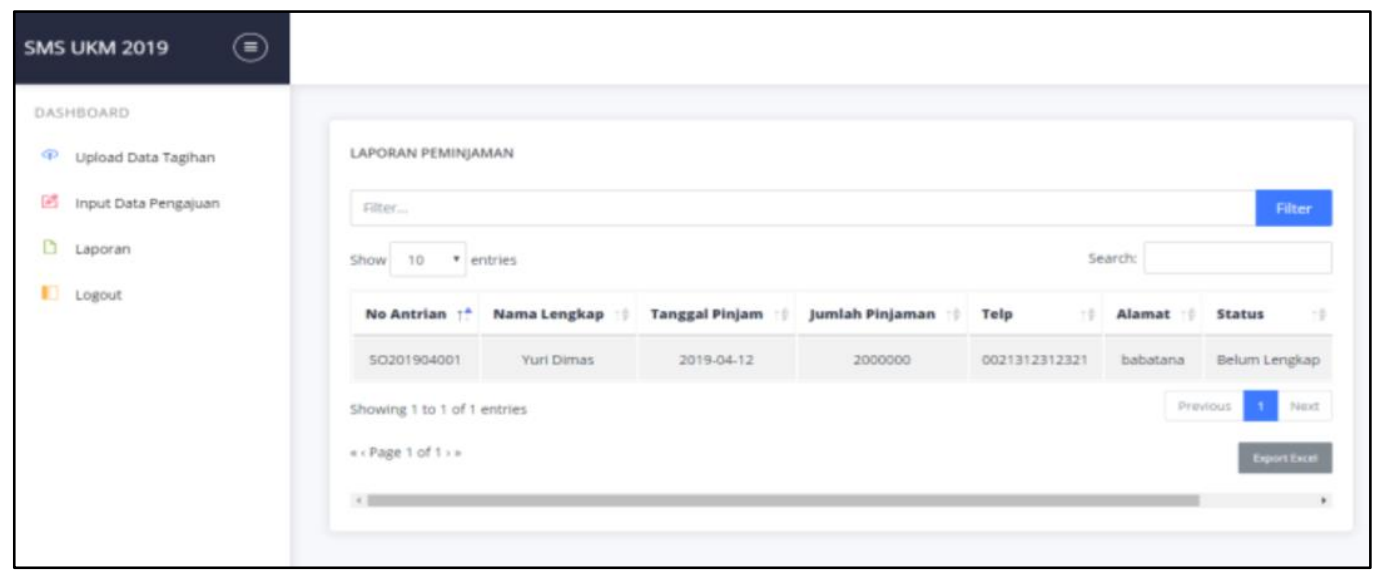

Gambar 7. Tampilan Menu Laporan

Menu Laporan digunakan untuk menampilkan dan membuat laporan terkait data peminjaman. Pengguna dapat mengatur data laporan yang ingin ditampilkan dengan menggunakan fitur filter data yang tertera di sisi atas tabel tampilan data peminjaman. Pengguna juga dapat mengatur jumlah tampilan data laporan per page atau halaman dengan mengubah jumlah yang tertera pada "SHOW [rubah angka] ENTRIES". Selain itu, pengguna juga dapat mengunduh laporan ke dalam format .xlsx (Microsoft Excel) dengan menekan tombol "EXPORT EXCEL" (berwarna abu-abu) pada sisi bawah kanan tabel.

Dengan adanya aplikasi notifikasi maka akan membawa perubahan pada pola kerja pada Unit UKM Koperasi Wanita Setia Bhakti Wanita Jawa Timur. Berikut ini adalah beberapa perubahan yang terjadi setelah implementasi aplikasi notifikasi:

1. PJ Pinjaman harus memasukkan data pengajuan pinjaman dan perkembangan pengajuan pinjaman anggota melalui aplikasi notifikasi 
2. Bagian Informasi secara berkala melalukan sinkronisasi data tagihan dari Sistem Informasi UKM dengan Aplikasi Notifikasi.

3. Bagian Informasi bisa mengirimkan notifikasi berdasarkan daftar pinjaman yang akan jatuh tempo, sedang jatuh tempo dan telah melewati jatuh tempo. Pengiriman SMS notifikasi dilakukan dengan terlebih dahulu memverifikasi tagihan, jika sudah valid maka tinggal menekan button kirim, maka SMS akan dikirimkan ke semua nomor handphone yang sudah didaftarkan pada waktu proses pengajuan pinjaman.

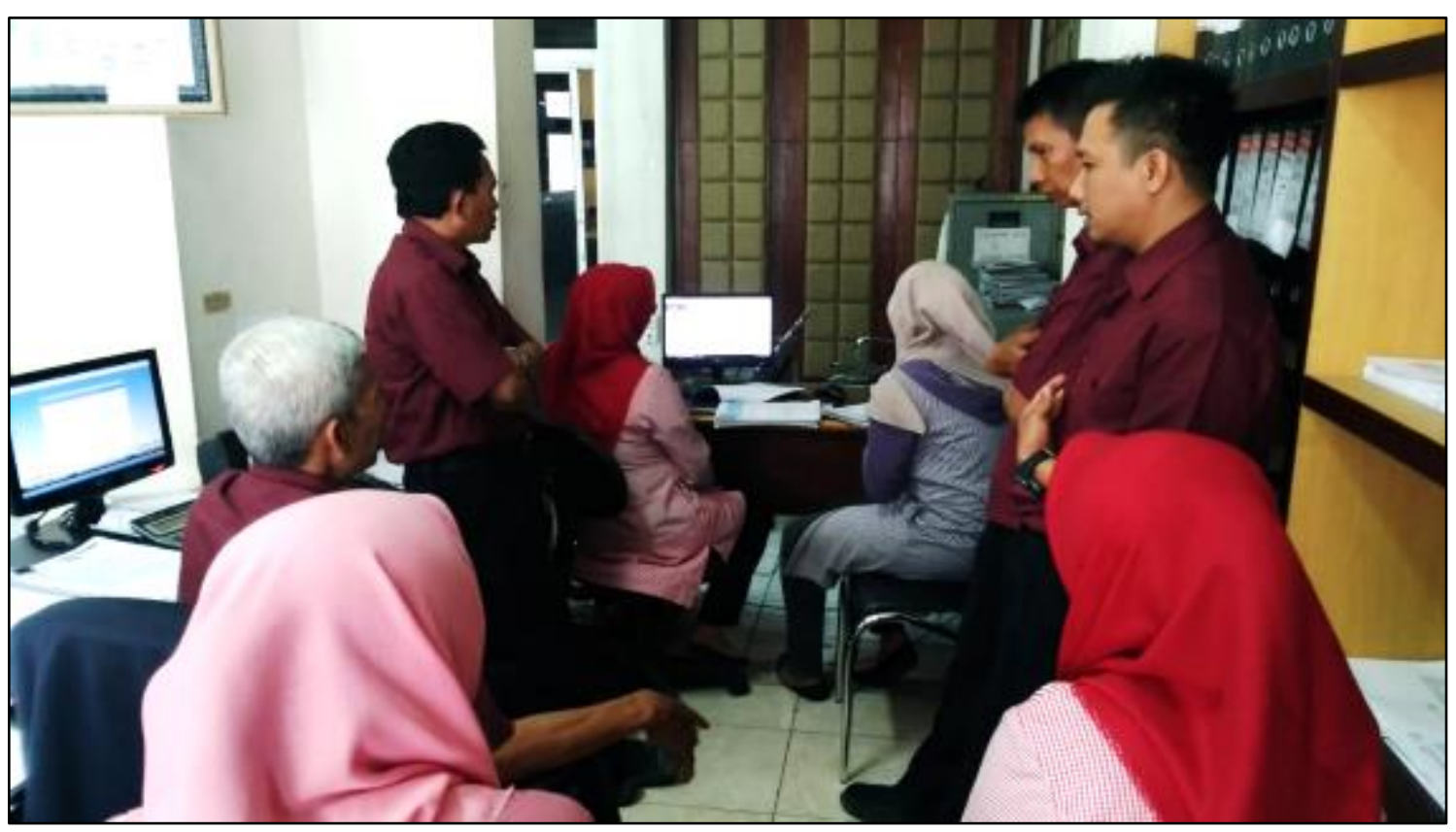

Gambar 8. Kegiatan Instalasi Aplikasi Notifikasi

Proses instalasi dilaksanakan pada tanggal 3 Juli 2019 (lihat Gambar 8), dengan urutan kegiatan sebagai berikut (lihat Tabel 2):

Tabel 2. Kegiatan Instalasi Aplikasi Notifikasi

\begin{tabular}{|c|c|c|c|}
\hline NO & KEGIATAN & $\begin{array}{l}\text { PERALATAN/PERANGAT } \\
\text { LUNAK }\end{array}$ & KETERANGAN \\
\hline 1 & $\begin{array}{l}\text { Instalasi Web } \\
\text { Server }\end{array}$ & Apache Web Server & $\begin{array}{l}\text { Server untuk } \\
\text { menjalankan aplikasi }\end{array}$ \\
\hline 2 & $\begin{array}{l}\text { Installasi MySQL } \\
\text { Server }\end{array}$ & MySQL Server Community Edition & $\begin{array}{l}\text { Program untuk } \\
\text { mengelola basis data }\end{array}$ \\
\hline 3 & $\begin{array}{l}\text { Instalasi Driver } \\
\text { Modem GSM }\end{array}$ & USB Serial Driver & $\begin{array}{l}\text { Driver modem GSM } \\
\text { supaya bisa } \\
\text { berkomunikasi } \\
\text { dengan Gammu }\end{array}$ \\
\hline 4 & Instalasi Gammu & Gammu & $\begin{array}{l}\text { Librari program } \\
\text { untuk } \\
\text { menghubungkan } \\
\text { aplikasi dengan } \\
\text { modem dan database }\end{array}$ \\
\hline 5 & $\begin{array}{l}\text { Konfigurasi } \\
\text { Gammu }\end{array}$ & Notepad++ & $\begin{array}{l}\text { Setting database dan } \\
\text { parameter modem }\end{array}$ \\
\hline 6 & Inisialisasi Data & Web Browser & $\begin{array}{l}\text { Memasukkan data } \\
\text { awal dari aplikasi }\end{array}$ \\
\hline
\end{tabular}




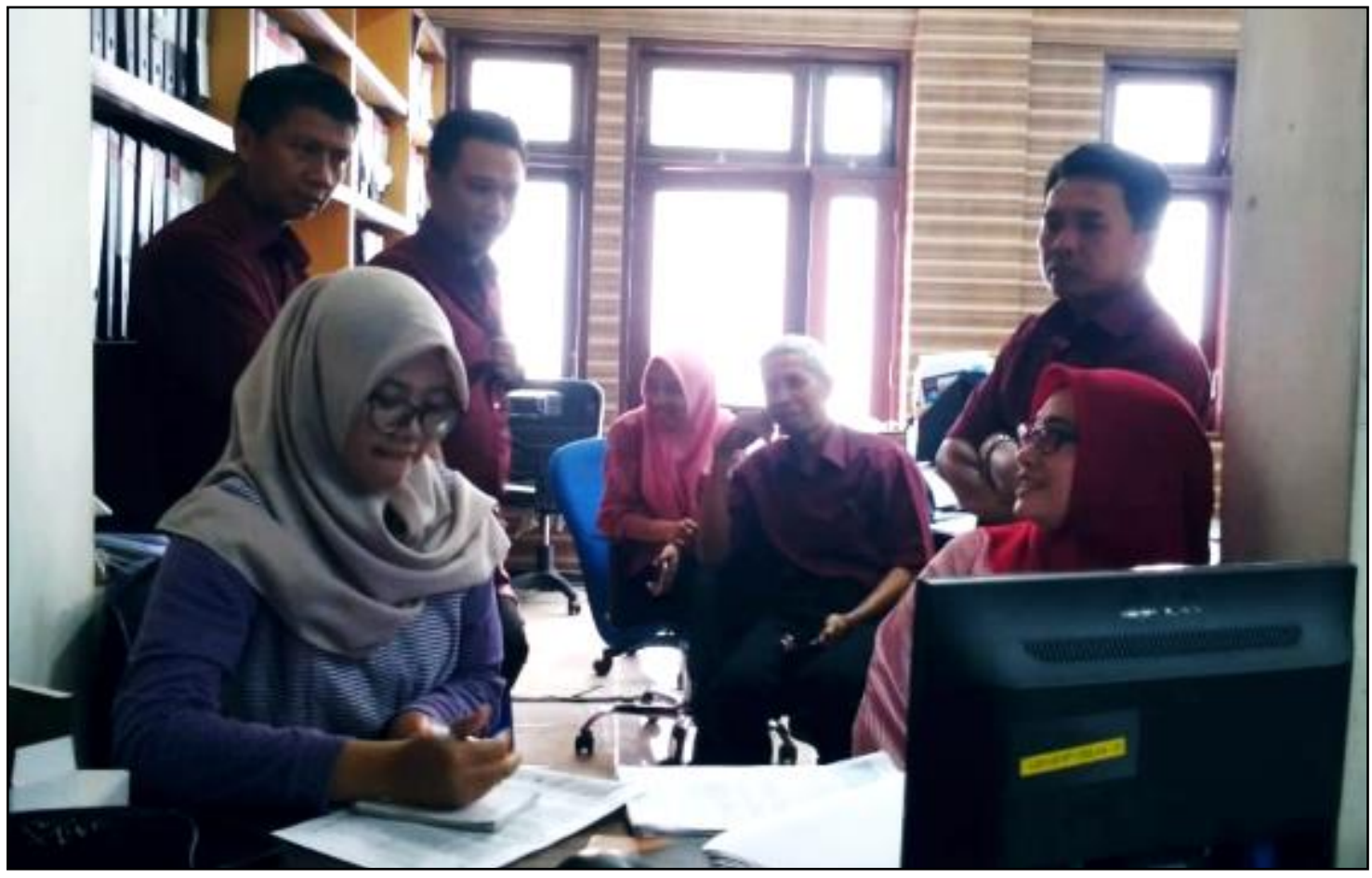

Gambar 9. Pelatihan Pengoperasian Aplikasi Notifikasi

Pelatihan pengoperasian Aplikasi Notifikasi dilaksanakan setelah proses instalasi yaitu pada tanggal 3 Juli 2019 (Gambar 9). Pelatihan diikuti oleh 8 peserta yang terdiri dari: 7 peserta dari Unit UKM dan 1 Peserta dari Unit EDP. Materi utama pelatihan adalah: membuka aplikasi, melakukan login, menambahkan data penerima SMS, import data tagihan, menampilkan data tagihan dan mengirimkan notifikasi berdasarkan data tagihan. Hasil pelatihan menunjukkan peserta dapat mengoperasikan aplikasi terlihat dari berhasilnya menambah data penerima sms dan penambahan data tagihan.

\section{KESIMPULAN}

Implementasi aplikasi notifikasi berbasis SMS Gateway ini menjadi salah satu solusi bagi Unit UKM Koperasi Wanita Setia Bhakti Wanita Jawa Timur dalam melaksanakan proses bisnis Unit UKM dan dapat mencegah dan mengurangi masalah pinjaman macet pada anggota koperasi. Secara umum pelaksanaan pengabdian masyarakat ini berjalan dengan baik. Para karyawan pada Unit UKM dengan antusias terlibat dalam kegiatan ini, mulai dari perencanan hingga implementasi dan pelatihan penggunaan aplikasi.

Dengan adanya aplikasi notifikasi ini maka catatan riwayat pengiriman SMS notifikasi ke anggota dapat tersimpan dengan baik secara digital dan mudah untuk dicari jika dibutuhkan. Dengan adanya riwayat pengiriman SMS notifikasi maka dapat digunakan sebagai bukti ke anggota bahwa pihak koperasi sudah memberikan peringatan terkait status dari pinjaman anggota yang bermasalah. Terdapat kekurangan aplikasi pada proses pembacaan tagihan yang masih dilaksanakan secara manual yaitu mengimport dari file teks yang dieksport oleh System UKM. Saran pengembangan berikutnya adalah melakukan migrasi basis System UKM dari data file ke basis data relasional sehingga tagihan bisa secara otomatis masuk ke dalam tabel Tagihan pada Aplikasi Notifikasi berbasis SMS Gateway. 


\section{UCAPAN TERIMAKASIH}

Penulis mengucapkan terima kasih kepada Koperasi Wanita Setia Bhakti Wanita Jawa Timur atas kerjasama dan dukungan dalam proses implementasi aplikasi notifikasi berbasis SMS Gateway yang telah dilaksanakan mulai tanggal 1 Januari 2019 sd 30 Juli 2019.

\section{DAFTAR PUSTAKA}

Dennis, A., WIXOM, B. H., \& ROTH, R. M. (2012). SYSTEM ANALYSIS AND DESIGN Fifth Edition. NY: John Wiley \& Sons, Inc.

Laraswati, D., \& Syam, E. (2019). IMPLEMENTASI SMS GATEWAY SEBAGAI SISTEM INFORMASI KEUANGAN SISWA(STUDI KASUS : SMP NEGERI 6 SINGINGI HILIR). JURNAL TEKNOLOGI DAN OPEN SOURCE VOL. 2 No. 1, Juni 2019, 65-73.

Semaun, S. (2018). EKSISTENSI KOPERASI WANITA DALAM MENINGKATKAN PENDAPATAN MASYARAKAT. Jurnal Al-Maiyyah, Volume 11 No. 2 Juli - Desember 2018, 190-213.

Sulianta, F. (2019). Strategi Merancang Arsitektur Sistem Informasi. Bandung: Kompas Gramedia.

Sulistiawati, \& Sulistiani, H. (2017). PERANCANGAN DASHBOARD INTERAKTIF PENJUALAN (STUDI KASUS : PT JAYA BAKERY). Jurnal TEKNO KOMPAK, Vol. 12, No. 1, 2018, 15-17.

Unhelkar, B. (2018). Software Engineering with UML. Boca Raton: CRC Press. 